\title{
OVERVIEW OF INDICATOR DEVELOPMENT IN THE FIELDS OF SUSTAINABLE DEVELOPMENT AND ENVIRONMENTAL PROTECTION
}

\author{
UDC 502.131.1
}

\author{
Žarko Vranjanac \\ University of Niš, Faculty of Occupational Safety, Niš, Serbia
}

\begin{abstract}
This paper discusses the historical development, terminological definition, and the theoretical definition of indicators used in the fields of sustainable development and environmental protection. Since numerous indicators are used in a variety of scientific fields and since new indicators are constantly being developed, special focus is given to the types of indicators. Individual, derived, composite, or 'super' indicators are increasingly used to show a state and changes of a given state of a specific phenomenon or concept. Thus formed indicators constitute an important segment in the monitoring of the state of the environment and in the monitoring of sustainable development, on the basis of which decisions can be made. Such indicators are extensively used in the fields of sustainable development and environmental protection, and the aim of this review was to help better understand their essence.
\end{abstract}

Key words: indicators, environmental protection, sustainable development, management

\section{INTRODUCTION}

From the dawn of humanity to this day, people felt the need to quantify phenomena and objects from nature and their surroundings. Natural resources have always been the most valuable, so a crucial task was to determine the units of measurement for surface area (surface area of pyramids, palaces, houses, and other structures). The following task was to determine the units of measurement for volume, which was necessary for proper water supply to the population. The depth of the Nile was the first to be measured, and it was 6 cubits and 1 palm deep [1]. In ancient Greece, units of measurement were determined using the length of body parts and objects from everyday life, and were classified as larger or smaller. However, it is widely believed that measurement became truly important with the emergence of goods and their exchange. Not all Athenians were of the same physical constitution, which is why equal

Received September 23, 2019 / Accepted December 9, 2019

Corresponding author: Žarko Vranjanac

Faculty of Occupational Safety, Čarnojevića 10a, 18000 Niš, Serbia

E-mail: zarko.vranjanac@znrfak.ni.ac.rs 
distribution of goods was difficult and with it, the communication among customers and merchants. This indicates that the comparison of ancient measures provided a basis for the later development of unified units of measurement, necessary for the comprehension of different social and natural phenomena. It is common in multidisciplinary sciences for a true value of a measured quantity to remain unknown due to measurement imperfections, which is why the manner or technique of measurement is so vital. The definition of how to determine the values of different objects, or the operationalization of variables, is the establishment of an empirical way to represent a theoretical variable. Since in that case the empirical variable is the indicator of the theoretical variable, it is defined as an indicating variable or an indicator $[2,3]$. In other words, indicators were introduced as indirect and partial measures of complex phenomena that are difficult to measure directly.

\section{ORIGIN AND HISTORICAL DEVELOPMENT OF INDICATORS}

In natural and technical sciences, the use of indicators is as old as measurement, whereas indicators were introduced to society more gradually, in multiple stages. In the early $19^{\text {th }}$ century, social reformists in Belgium, France, England, and the United States of America began using statistical indicators to improve public health and social conditions. In Europe, physicians and statisticians were at the forefront of indicator development, seeking ways to understand the nature of epidemics in industrialized cities. By using data, which were collected for the first time during this period, they developed causal models that showed how a specific disease was connected to poverty and other social conditions. In the United States, reformists and religious groups were actually developing indicators by associating alcohol consumption with crime, depravity, poverty, and economic wastefulness. Having collected data from poor parts of towns and prisons, they created tables containing data on the number of prisoners still awaiting trial for each of the previous five years. They did this to indicate poor performance of prosecutors and the judiciary system. Then they calculated the number of hectares dedicated to the production of liquor (similar to the modern ecological footprint analysis) to show how much alcohol was economically wasteful. Breweries were consequently additionally taxed and were forced to allocate funds for the care of the poor population. The end of the $19^{\text {th }}$ century in the USA and Europe was ridden with conflicts about wages, unemployment, and work conditions. That is when the first institutions dealing with statistics were founded, such as the Bureau of Labor Statistics in Massachusetts (1869), and the American Bureau of Labor (1884) [4]. The early $20^{\text {th }}$ century was marked by an interest in the development of economic, as well as demographic, educational, and health indicators. In the second half of the $20^{\text {th }}$ century, analytical instruments were introduced into politics, so indicators became a major topic of concern in every field. Near the end of the $20^{\text {th }}$ century, books on this topic began to be published extensively and indicators were finally introduced into institutions such as WHO, OECD, EEA, and many more, which developed the indicators that we know today and that are continuously being improved. 


\section{THE TERM 'INDICATOR'}

The term indicator originates from the Latin verb indicare (show, point to, indicate) and the related Latin noun indicator (someone who points out) [5, 6]. Indicators are tools that show a specific state or changes in a specific state. Indicators and indexes (Lat. index) are tools meant to reduce a large amount of data to a simple form while preserving the essence of those data with added compactness and clear understanding [7]. While indicators are statistically directed to indicate specifically selected questions, which point to the results and conclusions of a given phenomenon, indexes show the relationships that point to the variations of one or more time or dynamic series [8]. Index can be synonymous to indicator [9]. Indexes connect different indicators into a single number, useful for temporal and spatial comparison, which is why composite (combined) indicators are often referred to as indexes in literature, while the term indicator refers only to individual indicators [10]. It must be noted that indicators are not to be confused with terms such as performance, parameter, etc. The term performance refers to a socially constructed performance of an observed phenomenon [11], whereas the term parameter refers to finite (boundary) properties of a system [12, 13]. For instance, in statistics, parameters represent numerical properties of a population (mean, arithmetic mean, etc.). The field of environmental protection often requires the use of physicochemical parameters, e.g. pressure, temperature, density, humidity, speed, intensity, and many more. Therefore, it is pointless to equate the terms performance or parameter with indicators, since the level of information they provide is different. Whereas performance pertains to the level of success of a task or operation and parameters pertain to measures of properties, both on the level of data, indicators show the essence of a given phenomenon at the information level.

\subsection{Definition of indicators}

Indicators are widely accepted and used in natural, social, technical, and medical sciences, so there is no uniform definition of indicators. The World Health Organization (WHO) defines indicators as "variables that help to measure changes, directly or indirectly" [14]. The Organisation for Economic Co-operation and Development (OECD) defines an indicator as a "quantitative or qualitative factor or variable that provides a simple and reliable means to measure achievement, to reflect the changes connected to an intervention, or to help assess the performance of a development actor" [15]. According to the definition adopted by the U.S. Agency for International Development (USAID), an indicator is "a variable, of which the purpose is to measure change in a phenomenon or process" [16]. The European Statistical Office (EUROSTAT) defines indicators as "a description of the project's objectives in terms of quantity, quality, target group(s), time and place" [17]. In the American interpretation, an indicator is equal to a variable, while the European interpretation often includes the temporal factor and the basic and target value of a variable. According to the latter interpretation, indicators are used to elaborate the set goals, which are formulated generally. In everyday use, the term indicator refers to an instrument that provides information. Yet, the task of an indicator is to reach the level of information regarding management and decision making (usually through monitoring and evaluation), which requires data to be collected and statistically processed. 


\subsection{Types of indicators}

In multidimensional phenomena, which cannot be covered by only one indicator, individual indicators, together with the corresponding weight coefficients, are integrated into a single composite (Lat. componere - compile, compose) indicator (see Fig. 1). Some authors think that composite indicators are a result of globalization and that they are widely used due to simplicity of collection and translation as well as interpretation of shared trends of various phenomena $[18,19]$. Composite indicators are increasingly used to illustrate complex and hard-to-grasp issues, such as environmental protection or sustainable development.

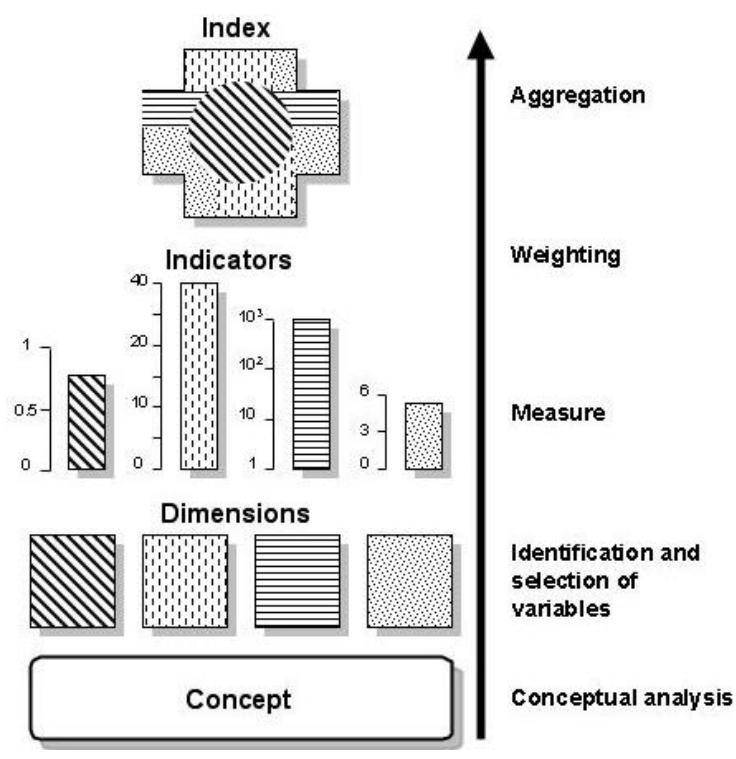

Fig. 1 Indicators in multidimensional concept [20]

Franceschini introduced the term 'super-indicator' referring to an indicator aggregated on a higher level and derived so as to synthesise all aspects of a phenomenon under investigation (see Fig. 2). Individual indicators $\left(\mathrm{I}_{1}\right.$ and $\left.\mathrm{I}_{2}\right)$ are first aggregated into one derived indicator $\left(\mathrm{I}_{4}\right)$, and then all the indicators $\left(\mathrm{I}_{1}, \mathrm{I}_{2}, \mathrm{I}_{3}\right.$, and $\left.\mathrm{I}_{4}\right)$ are aggregated into a single composite indicator $\left(\mathrm{I}_{5}\right)$, which synthesises all information [21].

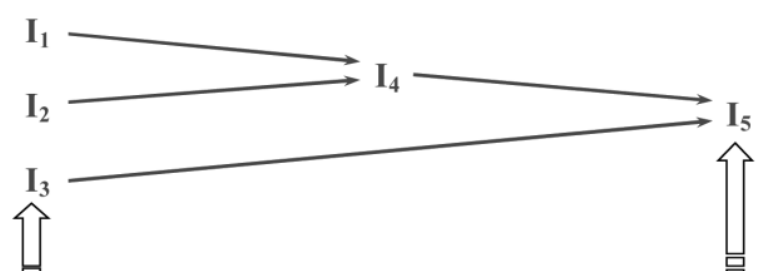

Fig. 2 Review of 'super-indicator' [21]

Indicators are often joined together if used for describing the same phenomenon. When individual and composite indicators are thus joined, they constitute a set or a family of 
indicators. Each indicator in a set represents a specific dimension as the distinguishing aspect of the generic process examined. Official institutions frequently use lists of the most important indicators to be monitored (e.g. List of 100 Core Health Indicators, National List of Environmental Indicators, etc.), while the indicator databases (e.g. World Bank or OECD databases) make the data available to all users. Some of the most representative indicators of sustainable development in the world are: Providing long-term ecological sustainability (ecological footprint); Meeting basic human needs (human development index); Promoting intergenerational equality (Gini coefficient); Promoting intergenerational equality (share of renewable energy in primary production or energy consumption) [22]. Certainly, it is expected that in the future the importance of income indicators with Global indicator framework for the Sustainable Development Goals and targets of the 2030 Agenda for Sustainable Development. In the area of environmental protection, EEA, WDI, OECD and national-level indicators are most commonly exploited in Europe. Indicators such as the Environmental Performance Index and the Air Quality Index are gaining in importance given the current state of the environment. Several environmental indicators have been developed in the Republic of Serbia, the most notable of which are Serbian Water Quality Index, Index of Drying Efficiency of Air, etc.

\section{CONCLUSION}

This paper reviewed the origin and historical development of indicators, as well as their terminological definition. It presented different definitions of indicators, with two prominent viewpoints. The European approach to planning emphasizes the development of indicators as early as in the formulation phase as crucial. When the goals are still unclear, indicators are necessary in order to obtain information about a target group, the timeframe, and the basic and target values. The indicators thus conceived enable proper resources and budget allocation for environmental projects, as well as operational planning. On the other hand, the American approach stresses that the schedule and target groups be defined first within the overall goals, and that indicators should be applied after the plan has been completed, a good example being the UN Millennium Development Goals. The paper also discussed several types of indicators, specifically individual, derived, composite, and 'super' indicators. The paper also lists some of the most significant indicators in the field of sustainable development and environmental protection in the World, Europe, as well as in Serbia. This paper has pointed out the importance of indicators, as well as a better understanding of the terminology of indicators and their essence.

Acknowledgement: The paper is a part of the research done within the project No. III-43014, funded by the Serbian Ministry of Education, Science and Technological Development.

\section{REFERENCES}

1. Howarth, P., Redgrave, F., (2008), Metrology - in short, 3rd edition, EURAMET project 1011, p. 14.

2. Giles, D., (2017), On the Inconsistency of Instrumental Variables Estimators for the Coefficients of Certain Dummy Variables, Journal of Quantitative Economics, Vol.1, No.15, pp. 15-26.

3. Hendry, D., Santos C., (2005), Regression Models with Data- based Indicator Variables. Oxford Bulletin of Economics and Statistics, University of Oxford, Department of Economics.

4. Cobb, W.C., Rixford, C., (1998), Lessons learned from the history of social indicators. Redefining progress, San Francisco, CA. 
5. Hammond, A., Adriaanse, A., Rodenburg, E., Bryant, D., Woodward, R., (1995), Environmental Indicators: A Systematic Approach to Measuring and Reporting on Environmental Policy Performance in the Context of Sustainable Development, World Resources Institute, New York Avenue, Washington, D.C. 20006. ISBN 156973-026-1

6. Vranjanac, Ž., Indeks težine povreda na radu kao indikator stanja zaštite na radu (Index of occupational injuries as an indicator of safety at work), Fakultet zaštite na radu u Nišu, 2013, str. 8 (in serbian).

7. Veljković, N., Indikatori kvaliteta površinskih voda sa aspekta integralnog upravljanja održivim industrijskim i urbanim razvojem u slivu Južne morave (Indicators of surface water quality in terms of sustainable integrated management of industrial and urban development in the basin of South Morava), Fakultet zaštite na radu u Nišu, 2000, str. 25 (in serbian).

8. Veljković, N., Indeks razvoja ekoaglomeracija kao indikator održivog razvoja (Index of eco-agglomerations development as an indicator of sustainable development), Fakultet zaštite na radu u Nišu, 2004, str. 53 (in serbian).

9. Jacobs, R., Goddard, M., Smith, P., (2006), "Publicservices: Are composite measures a robust reflection of performance in the public sector?", University of York: Centre for Health Economics, Research Paper 16.

10. Jovičić, M. 2006. Kompozitni indeks - Magistrala multikriterijumske analize, Odgovor na osvrt „Kartografija stranputica na tržištu rada“ (Composite Index - Master of Multicriteria Analysis, Response to Review "Cartography of Labor Market Sidewalks"), Ekonomski anali br.171 / 2006 (in serbian).

11. Folan, P., Browne, J., Jagdev, H., (2015) Performance: Its meaning and content for today's business research. Journal Computers in industry, University of Exeter, UK.

12. Aster, R., Borchers, B., Thurber C., (2019) Parameter Estimation and Inverse Problems, $3^{\text {rd }}$ Edition. Elsevier Inc.

13. Aster, R., Borchers, B., Thurber C., (2013) Parameter Estimation and Inverse Problems, $2^{\text {nd }}$ Edition. Elsevier Inc.

14. Development of Indicators for Monitoring Progress towards Health for All by the year 2000, World Health Organization, 1981, Geneve, Switzerland.

15. Reader's guide Definition of OECD indicators of agricultural support, In Agricultural Policy Monitoring and Evaluation 2017, OECD, 2017, OECD Publishing, Paris, France. https://doi.org/10.1787/agr_pol-2017-2-en

16. FFP Indicators Handbook, Part II: Annual Monitoring Indicators, USAID, 2017, Washington, D.C., United States.

17. Guide to statistics in European Commission development co-operation, 2017 edition. Collection: Manuals and guidelines, EUROSTAT, 2017, Brussels, Belgium.

18. Beninni, A., (2012), Composite measures. Retrieved August 14, 2019, from http://aldobenini.org/Level2/HumanitData/ACAPS_CompositeMeasures_Note_120.

19. Saltelli, A., (2007) Composite Indicators between Analysis and Advocacy, Social Indicators research, No. 81, Vol. 1, pp. 65-77.

20. Boulanger, M.P., (2008), Sustainable development indicators: a scientific challenge, a democratic issue. SAPIENS, Vol 1., No. 1, pp. 45-59.

21. Franceschini, F., Galetto, M., Maisano, D., (2006), Classification of performance and quality indicators in manufacturing, Int. J. Services and Operations Management, Vol. 2, No. 3.

22. Holden, E., Linnerud, K., Banister, D., (2014), Sustainable development: Our Common Future revisited. Global Environmental Change, Vol. 26, pp. 130-139.

\section{PREGLED RAZVOJA INDIKATORA U OBLASTI ODRŽIVOG RAZVOJA I ZAŠTITE ŽIVOTNE SREDINE}

U radu je predstavljen istorijski razvoj, pojmovno određenje i definicija indikatora koji su $u$ primeni u oblasti održivog razvoja i zaštite životne sredine. S obzirom da je u upotrebi veliki broj indikatora u različitim naučnim oblastima, kao i da se kontinuirano formiraju novi indikatori, značajan akcenat usmeren je na vrste indikatora. Pojedinačni, izvedeni, kompozitni $i$ „super" indikatori, sve više su u upotrebi da bi pokazali stanje i promene u izvesnom stanju određenog fenomena (koncepta). Tako formirani indikatori predstavljaju značajan segment praćenja stanja u životnoj sredini, kao i praćenja održivog razvoja na osnovu kojih se mogu donositi odluke. S obzirom da se takvi indikatori široko primenjuju u oblasti održivog razvoja i zaštite životne sredine, ovaj pregledni rad imao je za cilj da ukaže na njihovo bolje razumevanje, kao i suštinu.

Ključne reči: indikatori, zaštita životne sredina, održivi razvoj, upravljanje 